\title{
Salt accumulation and distribution in a greenhouse soil as affected by salinity of irrigation water and leaching management
}

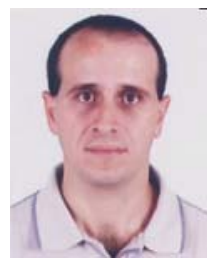

Flávio F. Blanco ${ }^{1} \&$ Marcos V. Folegatti

\begin{abstract}
1 ESALQ/USP. CEP 13418-900, Piracicaba, SP. Fone: (19) 3429-4217, Ramal: 268. E-mail: ffblanco@carpa.ciagri.usp.br (Foto)
${ }^{2}$ ESALQ/USP. Fone: (19) 3429-4380. E-mail: mvfolega@carpa.ciagri.usp.br
\end{abstract}

Protocolo $43-8 / 4 / 2002$

\begin{abstract}
The effects of irrigation water salinity, leaching fraction and its frequency of application on soil salinization were studied. Three water salinities $\left(S_{1}=1.54, S_{2}=3.10\right.$ and $S_{3}=5.20 \mathrm{dS} \mathrm{m}^{-1}$ ) and two irrigation water depths associated with their application frequencies $\left(\mathrm{W}_{1}=1.00 \mathrm{ETc}\right.$; $\mathrm{W}_{2} \mathrm{~F}_{1}=1.25 \mathrm{ETc}$ in all irrigations and $\mathrm{W}_{2} \mathrm{~F}_{2}=1.25 \mathrm{ETc}$ when the irrigation water depth of $\mathrm{W}_{1}$ reached $100 \mathrm{~mm}$ where ETc is the crop evapotranspiration), were applied during the growing period of a grafted-cucumber crop in a greenhouse. The experimental design consisted of randomized blocks of $3 \times 3$ factorial scheme with 3 replications. Soil salinity at $0.1,0.3$ and 0.5 $\mathrm{m}$ depths increased linearly with salinity levels of water and the leaching fraction did not have any effect regardless of its management. Salt concentration was higher near the soil surface and between the adjacent drippers.
\end{abstract}

Key words: salinization, leaching fraction, leaching frequency

\section{Acúmulo e distribuição de sais no solo em um ambiente protegido em função da salinidade da água de irrigação e manejo da lixiviação}

\begin{abstract}
Resumo: Estudaram-se os efeitos da salinidade da água de irrigação, fração de lixiviação e sua freqüência de aplicação na salinização de um solo. Durante um ciclo de pepino enxertado em ambiente protegido, foram aplicadas águas de diferentes salinidades $\left(\mathrm{S}_{1}=1,54, \mathrm{~S}_{2}=3,10\right.$ e $S_{3}=5,20 \mathrm{dS} \mathrm{m}^{-1}$ ) e duas lâminas de irrigação associadas às suas freqüências de aplicação $\left(\mathrm{W}_{1}=1,00 \mathrm{ETc} ; \mathrm{W}_{2} \mathrm{~F}_{1}=1,25 \mathrm{ETc}\right.$ em todas as irrigações e $\mathrm{W}_{2} \mathrm{~F}_{2}=1,25 \mathrm{ETc}$ quando a lâmina de irrigação acumulada em $W_{1}$ alcançou $100 \mathrm{~mm}$ em que ETc é a evapotranspiração da cultura). O delineamento experimental foi o de blocos casualizados em esquema fatorial $3 \times 3$ com 3 repetições. A salinidade do solo nas profundidades de 0,1, 0,3 e 0,5 m aumentou linearmente com a salinidade e a fração de lixiviação não teve efeito independente do seu manejo. A concentração de sais foi maior próximo à superfície do solo e na região compreendida entre dois gotejadores.
\end{abstract}

Palavras-chave: salinização, fração de lixiviação, eficiência da lixiviação

\section{INTRODUCTION}

Salinization is a process whereby the concentration of total dissolved solids in water and soil increases due to natural or human-induced processes (Ghassemi et al., 1995). Many times under irrigated conditions, salts dissolved in irrigation water may increase soil salinity, resulting in a salinity level higher than that tolerated by the crop. Water uptake by plants and evaporation from the soil surface are the causes of salt accumulation in root zone and the salt concentration is proportional to the water volume removed by these processes (Bresler et al., 1982).

Irrigation is the only source of water for plants under greenhouse cropping, since the plastic cover does not allow the rain to reach the surface of soil. Thus, for soils with deep water table that allows one to ignore the capillary rise of water in the water balance, the irrigation depth should promote not only crop evapotranspiration but also leaching of excess salts from the root zone in order to maintain soil salinity in the root zone at a suitable level for the crop.

The main problems caused by soil salinization are the reduction of osmotic potential of the soil solution (which reduces the water availability for plants) and the toxicity of certain ions (Rhoades et al., 1992). In addition, changes in the chemical and physical properties of the soil, such as $\mathrm{pH}$, water infiltration rate and nutrient availability for plants, may occur.

Leaching is the solution to the problem of the salinity build up in soil irrigated with saline water (Ayers \& Westcot, 1985). 
By increasing the water volume applied in each irrigation, the soil salinity may be reduced as a result of the increased volume of water percolated below the root zone (Petersen, 1996). By reducing the leaching fraction, salt concentration in soil solution increases because only a small amount of the salts is absorbed by plants. Hereby, osmotic potential of the soil solution limits the crop yield and leaching becomes essential for obtaining satisfactory yields (Hoffman, 1980).

Investigators have reported that reduced plant water uptake from a zone of high salinity is by an increase in the uptake from a zone low in salinity (Lunin \& Gallantin, 1965; Shalhevet \& Bernstein, 1968). Although this takes place without significant reduction in yield, there is a general concern about how much salt can be stored in the root zone before leaching is needed (Hoffman, 1990). Hoffman and Durnford (1999) state that leaching may be accomplished continuously or at intervals of a few weeks to a few years, depending on the salinity control required.

In lysimeters, Francois (1981) showed that reduction in the yield of alfalfa was less than $25 \%$ while more than 14,30 and 45 $\mathrm{Mg} \mathrm{ha}^{-1}$ of salt was stored below the depths of $0.6,1.2$ and 1.8 $\mathrm{m}$ soil profiles. The deeper the soil profile, the greater the amount of salt accumulated before any yield reduction was observed. Drastic reductions in yield took place when the salt began to build up in the upper portion of the root zone. The study demonstrated that regardless of soil depth, alfalfa can be grown for a considerable period of time without leaching, if the upper part of the root zone is maintained at a low level of salinity.

The objective of this study was to evaluate the soil salinity build up during a cucumber season and the leaching efficiency when a leaching fraction was applied at two different frequencies, using water of three different salinity levels.

\section{MATERIAL AND METHODS}

The experiment was carried out in a greenhouse located at the experimental area of the Department of Rural Engineering of the Escola Superior de Agricultura "Luiz de Queiroz" - USP, in Piracicaba, SP. The area of the greenhouse was $110 \mathrm{~m}^{2}(6.3 \mathrm{x}$ $17.5 \mathrm{~m}$ ) with $2.8 \mathrm{~m}$ height of lateral opening, covered by a polyethylene film of $0.15 \mathrm{~mm}$ thickness and with lateral curtains, that were closed at night and during rainy periods in order to avoid the rain water reaching the experimental plots, that would result in undesired leaching. The soil characteristics are shown in Table 1.

Table 1. Percentages of clay, silt and sand, soil water content at saturation $\left(\theta_{\mathrm{S}}\right)$, field capacity $\left(\theta_{\mathrm{FC}}\right)$ and permanent wilting point $\left(\theta_{\mathrm{PWP}}\right)$ and bulk density of the soil

\begin{tabular}{|c|c|c|c|c|c|c|c|}
\hline \multirow{2}{*}{$\begin{array}{c}\text { Layer } \\
\mathrm{m}\end{array}$} & Clay & Silt & Sand & $\theta_{\mathrm{S}}$ & $\theta_{\mathrm{FC}}$ & $\theta_{\mathrm{PWP}}$ & \multirow{2}{*}{$\begin{array}{c}\text { Bulk } \\
\text { Density } \\
\mathrm{kg} \mathrm{dm}^{-3}\end{array}$} \\
\hline & \multicolumn{3}{|c|}{$\mathrm{g} \mathrm{kg}^{-1}$} & \multicolumn{3}{|c|}{$\mathrm{m}^{3} \mathrm{~m}^{-3}$} & \\
\hline & & & & & & & 140 \\
\hline & 50 & & & & & & \\
\hline $0.4-0.6$ & 520 & 130 & 350 & 0.436 & 0.391 & 0.303 & 1.52 \\
\hline
\end{tabular}

Three beds were prepared and divided into nine plots of $1.85 \mathrm{~m}$ length and $1 \mathrm{~m}$ width, which were isolated by a plastic film buried at $0.8 \mathrm{~m}$ depth to avoid salt movement between two adjacent plots. Two rows of grafted-cucumber were transplanted to the beds on June 23, 1999 with one dripper per plant. The distance between irrigation lines was $0.65 \mathrm{~m}$ and drippers with a discharge rate of $4.0 \mathrm{~L} \mathrm{~h}^{-1}$ were placed $0.40 \mathrm{~m}$ apart in the irrigation line. Each plot had a gate valve and the irrigation could be carried along in each plot separately.

Treatments were composed of three levels of water salinities $\left(\mathrm{S}_{1}=1.54, \mathrm{~S}_{2}=3.10\right.$ and $\left.\mathrm{S}_{3}=5.20 \mathrm{dS} \mathrm{m}^{-1}\right)$, two irrigation depths $\left(\mathrm{W}_{1}=1.0 \mathrm{ETc}\right.$ and $\left.\mathrm{W}_{2}=1.25 \mathrm{ETc}\right)$, where ETc is the estimated crop evapotranspiration, and two frequencies of $\mathrm{W}_{2}$ application $\left(\mathrm{F}_{1}=\right.$ in all irrigations and $\mathrm{F}_{2}=$ when the irrigation water depth of $\mathrm{W}_{1}$ reached $100 \mathrm{~mm}$ ). The water depths applied for $\mathrm{W}_{2} \mathrm{~F}_{2}$ were the same as that of the treatment $\mathrm{W}_{1}$. When the accumulated water depth applied in $\mathrm{W}_{1}$ reached $100 \mathrm{~mm}$, the plots under $\mathrm{W}_{2} \mathrm{~F}_{2}$ treatment received an irrigation of $25 \mathrm{~mm}$, thus equaling the total amount of water applied in $\mathrm{W}_{2} \mathrm{~F}_{1}$ treatment since the beginning of the experiment.

An evaporation pan located in the middle of the greenhouse between two beds and tensiometers installed at 0.15 and $0.30 \mathrm{~m}$ depths (placed at $0.10 \mathrm{~m}$ from the plant and the dripper) determined the irrigation requirements. Water was applied whenever the mean soil matric potential was below $-30 \mathrm{kPa}$. Irrigation water depth was calculated based on evaporation pan, using a pan coefficient (Kp) of 1.0 as recommended by MartínezRaya \& Castilla (1989) and Castilla et al. (1990). The water depth was also adjusted from the tensiometer readings at $0.30 \mathrm{~m}$ depth. When the tensiometer installed in the treatment $\mathrm{S}_{1} \mathrm{~W}_{1}$ (control treatment) indicated that soil moisture did not reach field capacity $24 \mathrm{~h}$ after irrigation, the crop coefficient $(\mathrm{Kc})$ for the next irrigation was increased, thus increasing the irrigation depth. This procedure was adopted because Kc values are not available for cucumber in greenhouse in Brazil and no lysimeter was available to determine the water consumption by plants. Irrigation frequency was once every three days, on average.

Ammonium sulphate, calcium nitrate, potassium nitrate, potassium chloride, phosphoric acid and magnesium sulphate fertilizers were applied. $\mathrm{S}_{1}$ water received only the fertilizers, while in $\mathrm{S}_{2}$ and $\mathrm{S}_{3}$ salts were added in order to obtain the required salinity. The salts were calcium chloride, magnesium sulphate and sodium chloride, which were mixed in order to obtain a nutritive solution for $\mathrm{S}_{2}$ and $\mathrm{S}_{3}$ with $(\mathrm{Na}+\mathrm{K})$ : $\mathrm{Ca}: \mathrm{Mg}$ ratio of $5: 3: 2$. The characteristics of the water applied in each treatment are shown in Table 2. Cations and anions concentration varied with time because the amount of fertilizer applied followed the cucumber's absorption rate; thus, the crop period was divided into three phases: Initial (weeks 3 and 4), Intermediate (weeks from 5 to 12) and Final (weeks from 13 to 17).

Saline water application began 19 days after transplanting (DAT) and the soil salinity (electrical conductivity of saturation extract), ECs, (Richards, 1954) was determined at 20, 76 and 117 DAT. Soil samples were taken at 0-0.2, 0.2-0.4 and 0.4-0.6 m depths, representing the average depths of $0.1,0.3$ and $0.5 \mathrm{~m}$, respectively, at two points of each row: $0.05 \mathrm{~m}$ from the dripper and $0.10 \mathrm{~m}$ from the plant (Figure 1). Sampling at 76 DAT was 
Table 2. Concentration of nutrients and salts, EC, pH and SAR of each water applied at different stages of cucumber season

\begin{tabular}{|c|c|c|c|c|c|c|c|c|c|c|c|}
\hline \multirow{3}{*}{ Characteristic } & \multirow{3}{*}{ Unit } & \multirow{3}{*}{$\begin{array}{c}\text { Tap } \\
\text { Water }\end{array}$} & \multicolumn{9}{|c|}{ Water Used In Treatments ${ }^{1}$} \\
\hline & & & \multicolumn{3}{|c|}{$\mathrm{S}_{1}$} & \multicolumn{3}{|c|}{$\mathrm{S}_{2}$} & \multicolumn{3}{|c|}{$\mathrm{S}_{3}$} \\
\hline & & & Initial & Interm. & Final & Initial & Interm. & Final & Initial & Interm. & Final \\
\hline $\mathrm{NO}_{3}{ }^{-}$ & $\mathrm{mmol}_{\mathrm{c}} \mathrm{L}^{-1}$ & - & 1.20 & 1.70 & 2.02 & 1.20 & 1.70 & 2.02 & 1.20 & 1.70 & 2.02 \\
\hline $\mathrm{NH}_{4}^{+}$ & $\mathrm{mmol}_{\mathrm{c}} \mathrm{L}^{-1}$ & - & 1.37 & 1.95 & 2.32 & 1.37 & 1.95 & 2.32 & 1.37 & 1.95 & 2.32 \\
\hline $\mathrm{PO}_{4}^{-3}$ & $\mathrm{mmol}_{\mathrm{c}} \mathrm{L}^{-1}$ & $0.01^{2}$ & 1.09 & 1.58 & 1.82 & 1.09 & 1.58 & 1.82 & 1.09 & 1.58 & 1.82 \\
\hline $\mathrm{K}^{+}$ & $\mathrm{mmol}_{\mathrm{c}} \mathrm{L}^{-1}$ & 0.07 & 4.18 & 4.90 & 5.76 & 4.18 & 4.90 & 5.76 & 4.18 & 4.90 & 5.76 \\
\hline $\mathrm{Ca}^{+2}$ & $\mathrm{mmol}_{\mathrm{c}} \mathrm{L}^{-1}$ & 0.69 & 4.60 & 4.96 & 5.84 & 7.31 & 7.37 & 7.40 & 20.30 & 12.70 & 13.20 \\
\hline $\mathrm{Mg}^{+2}$ & $\mathrm{mmol}_{\mathrm{c}} \mathrm{L}^{-1}$ & 0.45 & 0.31 & 0.45 & 0.53 & 4.34 & 8.19 & 3.70 & 8.82 & 18.06 & 8.75 \\
\hline $\mathrm{Na}^{+}$ & $\mathrm{mmol}_{\mathrm{c}} \mathrm{L}^{-1}$ & 0.24 & 0.00 & 0.00 & 0.00 & 12.10 & 11.60 & 10.50 & 23.50 & 23.34 & 23.40 \\
\hline $\mathrm{Cl}^{-}$ & $\mathrm{mmol}_{\mathrm{c}} \mathrm{L}^{-1}$ & 0.01 & 2.78 & 1.60 & 1.82 & 17.55 & 15.57 & 13.86 & 42.00 & 32.62 & 32.60 \\
\hline $\mathrm{SO}_{4}^{-2}$ & $\mathrm{mmol}_{\mathrm{c}} \mathrm{L}^{-1}$ & 0.48 & 2.20 & 3.20 & 3.72 & 6.34 & 6.90 & 7.00 & 10.90 & 11.64 & 12.10 \\
\hline $\mathrm{EC}$ & $\mathrm{dS} \mathrm{m}^{-1}$ & 0.22 & 1.40 & 1.54 & 1.68 & 3.10 & 3.01 & 3.20 & 5.36 & 5.08 & 5.15 \\
\hline $\mathrm{pH}$ & & 8.10 & 6.90 & 6.60 & 6.30 & 6.90 & 6.49 & 6.31 & 7.27 & 6.59 & 6.26 \\
\hline SAR & $\left(\mathrm{mmol}_{\mathrm{c}} \mathrm{L}^{-1}\right)^{1 / 2}$ & 0.32 & 0.14 & 0.13 & 0.12 & 4.88 & 4.10 & 4.34 & 6.10 & 5.90 & 6.96 \\
\hline
\end{tabular}

Initial: weeks 3 to 4; Intermediary: weeks 5 to 12; Final: weeks 13 to 17 after transplanting

${ }^{2} \mathrm{P}$ concentration, in $\mathrm{mg} \mathrm{L}^{-1}$

accomplished one day after $\mathrm{W}_{2} \mathrm{~F}_{2}$ treatments had received 25.75 $\mathrm{mm}$ of water, since the accumulated irrigation water depth applied on $\mathrm{S}_{1} \mathrm{~W}_{1}$ reached $103 \mathrm{~mm}$ in the prior irrigation. One plot in each of $\mathrm{S}_{3} \mathrm{~W}_{1}, \mathrm{~S}_{3} \mathrm{~W}_{2} \mathrm{~F}_{1}$ and $\mathrm{S}_{3} \mathrm{~W}_{2} \mathrm{~F}_{2}$ treatments was selected and samples were also taken between two drippers at $0.1 \mathrm{~m}$ interval at depths of $0-0.2,0.2-0.4,0.4-0.6$ and $0.6-0.8 \mathrm{~m}$, in order to determine the profile of salt distribution within and between the wet bulbs at the end of the experiment.

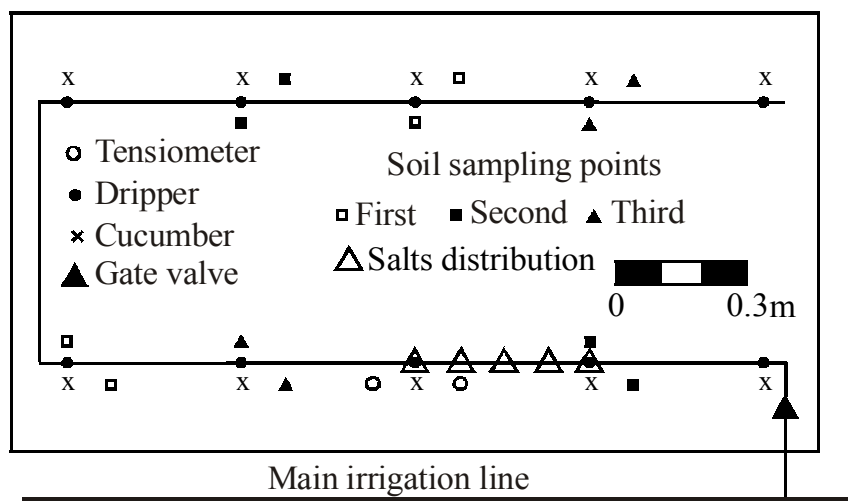

Figure 1. Scheme showing the relative position of plants, drippers, tensiometers and sampling points in a plot

The factors were arranged in a $3 \times 3$ factorial scheme, where the first was the water salinity $\left(\mathrm{S}_{1}, \mathrm{~S}_{2}\right.$ and $\left.\mathrm{S}_{3}\right)$ and the second the combination of irrigation water depths and leaching frequencies $\left(\mathrm{W}_{1}, \mathrm{~W}_{2} \mathrm{~F}_{1}\right.$ and $\left.\mathrm{W}_{2} \mathrm{~F}_{2}\right)$. The analysis of variance was carried out for each soil depth. In order to evaluate the influence of time on soil salinity build up, a multivariate analysis was performed and the significant interactions were analyzed by univariate analysis, as recommended by Morrison (1990).

\section{RESULTS AND DISCUSSION}

Multivariate statistical analysis (Table 3) showed that the time and its interaction with water salinity had significant effects on soil salinity (ECs) for every soil depth, which reveals that application of water of different salinity levels resulted in different ECs over the time. Therefore, leaching fraction and its management did not affect soil salinity build up with time. In other words, the application of $25 \%$ more water than that required to restore evapotranspirated water was not efficient in avoiding the soil salinity build up, independent of the frequency of application.

The univariate analysis (Table 4) showed that water salinity had a linear effect for each time interval and soil depth. As the water salinity effects were the same for all interactions, the Tukey's test was performed in order to verify the effects of each level of water salinity on ECs. As expected, increasing water salinity led to higher values of ECs for samples taken on 76 and on 117 DAT, but some variations occurred for the 20 DAT sampling. For the samples taken on 20 DAT, salinity values were not statistically different at $0.1 \mathrm{~m}$ depth for $\mathrm{S}_{1}$ and $\mathrm{S}_{2}$. The level $\mathrm{S}_{3}$ resulted in the highest value and differed significantly from the others. Soil salinity for $\mathrm{S}_{1}$ was significantly lower for 0.3 and $0.5 \mathrm{~m}$ depths than those for $\mathrm{S}_{2}$ and $\mathrm{S}_{3}$, which did not differ among themselves. In spite of these results, soil salinity increased with water salinity for all depths and sampling times.

Table 3. Results of multivariate statistical analysis of soil salinity for different soil depths

\begin{tabular}{|c|c|c|c|c|c|c|c|c|c|}
\hline \multirow{3}{*}{ Source } & \multicolumn{9}{|c|}{ Statistic } \\
\hline & \multicolumn{3}{|c|}{$0.1 \mathrm{~m}$} & \multicolumn{3}{|c|}{$0.3 \mathrm{~m}$} & \multicolumn{3}{|c|}{$0.5 \mathrm{~m}$} \\
\hline & Wilks & Pillai & Hotelling-Lawley & Wilks & Pillai & Hotelling-Lawley & Wilks & Pillai & Hotelling-Lawley \\
\hline $\mathrm{T}$ & $56.60 * *$ & $56.60 * *$ & $56.60 * *$ & $168.66 * *$ & $168.66 * *$ & $168.66^{* *}$ & $318.37 * *$ & $318.37 * *$ & $318.37 * *$ \\
\hline $\mathrm{T} \times \mathrm{S}$ & $3.88 *$ & $3.18^{*}$ & $4.54 * *$ & $12.50 * *$ & $6.03 * *$ & $21.38 * *$ & $22.39 * *$ & $7.12 * *$ & $51.81 * *$ \\
\hline $\mathrm{T} \times \mathrm{WF}$ & $0.24^{\mathrm{ns}}$ & $0.25^{\mathrm{ns}}$ & $0.22^{\mathrm{ns}}$ & $0.35^{\mathrm{ns}}$ & $0.37^{\mathrm{ns}}$ & $0.33^{\mathrm{ns}}$ & $0.60^{\mathrm{ns}}$ & $0.62^{\mathrm{ns}}$ & $0.58^{\mathrm{ns}}$ \\
\hline
\end{tabular}

$*$ ** Significant at 0.05 and 0.01 level of probability by Test $\mathrm{F}$, respectively

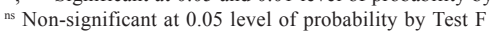


Table 4. Results of the univariate analysis of the irrigation water salinity effects on soil salinity for different depths and sampling times

\begin{tabular}{|c|c|c|c|c|c|c|c|c|c|}
\hline \multirow{3}{*}{ Source } & \multicolumn{9}{|c|}{ Soil Depth (m) } \\
\hline & \multicolumn{3}{|c|}{0,1} & \multicolumn{3}{|c|}{0,3} & \multicolumn{3}{|c|}{0,5} \\
\hline & 20 DAT & 76 DAT & 117 DAT & 20 DAT & 76 DAT & 117 DAT & 20 DAT & 76 DAT & 117 DAT \\
\hline & \multicolumn{9}{|c|}{$\mathrm{F}$} \\
\hline Water salinity & $13,75 * *$ & $39,35 * *$ & $60,10 * *$ & $10,19 * *$ & $98,93 * *$ & $78,13 * *$ & $29,69 * *$ & $101,91 * *$ & $181,38 * *$ \\
\hline Linear & $27,40 * *$ & $78,50 * *$ & $119,87 * *$ & $19,18 * *$ & $197,26^{* *}$ & $155,87 * *$ & $52,60 * *$ & $203,18 * *$ & $362,64 * *$ \\
\hline \multirow[t]{2}{*}{ Quadr. } & $0,11^{\mathrm{ns}}$ & $0,21^{\mathrm{ns}}$ & $0,32^{\mathrm{ns}}$ & $1,20^{\mathrm{ns}}$ & $0,61^{\mathrm{ns}}$ & $0,38^{\mathrm{ns}}$ & $6,78^{*}$ & $0,64^{\mathrm{ns}}$ & $0,13^{\mathrm{ns}}$ \\
\hline & \multicolumn{9}{|c|}{ Means $\left(\mathrm{dS} \mathrm{m}^{-1}\right)^{\#}$} \\
\hline $\mathrm{S} 1$ & $1,52 \mathrm{~b}$ & $1,74 \mathrm{c}$ & $2,13 \mathrm{c}$ & $0,51 \mathrm{~b}$ & $0,80 \mathrm{c}$ & $1,01 \mathrm{c}$ & $0,32 \mathrm{~b}$ & $0,47 \mathrm{c}$ & $0,71 \mathrm{c}$ \\
\hline $\mathrm{S} 2$ & $1,93 \mathrm{~b}$ & $2,94 \mathrm{~b}$ & $3,29 \mathrm{~b}$ & $0,73 \mathrm{a}$ & $1,45 \mathrm{~b}$ & $1,78 \mathrm{~b}$ & $0,58 \mathrm{a}$ & $1,01 \mathrm{~b}$ & $1,42 \mathrm{~b}$ \\
\hline $\mathrm{S} 3$ & $2,54 \mathrm{a}$ & 3,99 a & $4,45 \mathrm{a}$ & $0,85 \mathrm{a}$ & $2,16 \mathrm{a}$ & $2,62 \mathrm{a}$ & $0,67 \mathrm{a}$ & $1,60 \mathrm{a}$ & $2,42 \mathrm{a}$ \\
\hline
\end{tabular}

*,** Significant at 0.05 and 0.01 of probability by Test $\mathrm{F}$, respectively

ns Non-significant at 0.05 level of probability by Test $F$

* Means with the same letter in the columns do not differ at 0.05 level of probability by Tukey's Test

Discrepancies observed for the 20 DAT could be related to the spatial variability of soil salinity, due to residual fertilizers from previous experiments carried out in the area or due to the salinity of farmyard manure applied to soil nine months before the beginning of the cropping period.

Figure 2 shows the relation between water salinity levels and ECs at the last soil sampling. Soil salinity at $0.1,0.3$ and $0.5 \mathrm{~m}$ depths increased by 26,36 and $52 \%$, respectively, for each $1 \mathrm{dS} \mathrm{m}^{-1}$ increase in water salinity. It seems that the salinity of irrigation water has more pronounced effects on the salinity of deeper layers of soil but the increase in ECs was 0.64, 0.45 and $0.47 \mathrm{dS} \mathrm{m}^{-1}$, for depths of $0.1,0.3$ and $0.5 \mathrm{~m}$, respectively, indicating that the effects of increasing water salinity occur in the shallowest layer. Differences between the increase of ECs for the two deeper layers could be due to sampling errors and distribution of salts. Thus one can assume that the effect of increasing water salinity on ECs build up is the same for both the depths.

Distribution of salts within the soil profile (Figure 3) followed the same pattern of those observed by other investigators

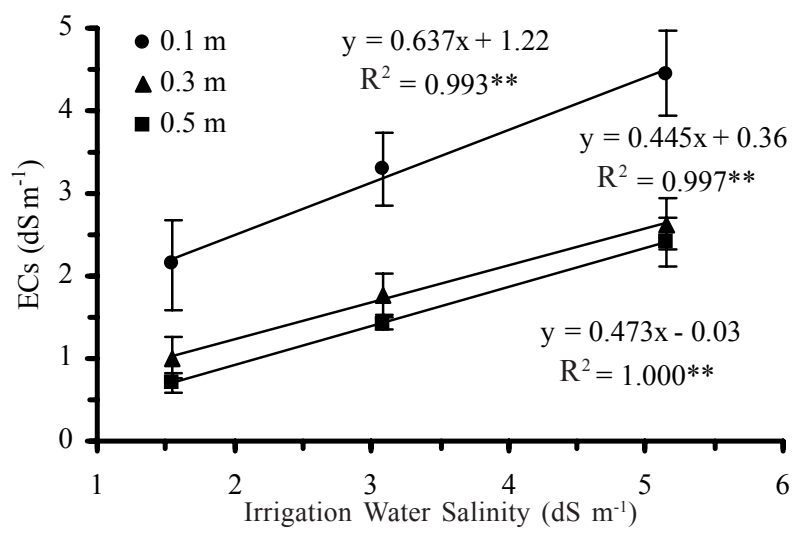

Figure 2. Soil salinity, ECs, at the last soil sampling accordingly to the salinity of irrigation water for each soil depth. Bars are the standard deviations

(Yaron et al., 1973; Bresler, 1975; Khan et al., 1996). Despite the absence of salinity reduction when $\mathrm{W}_{2}$ was applied, ECs at lower depths were higher as water depth increased. Factors
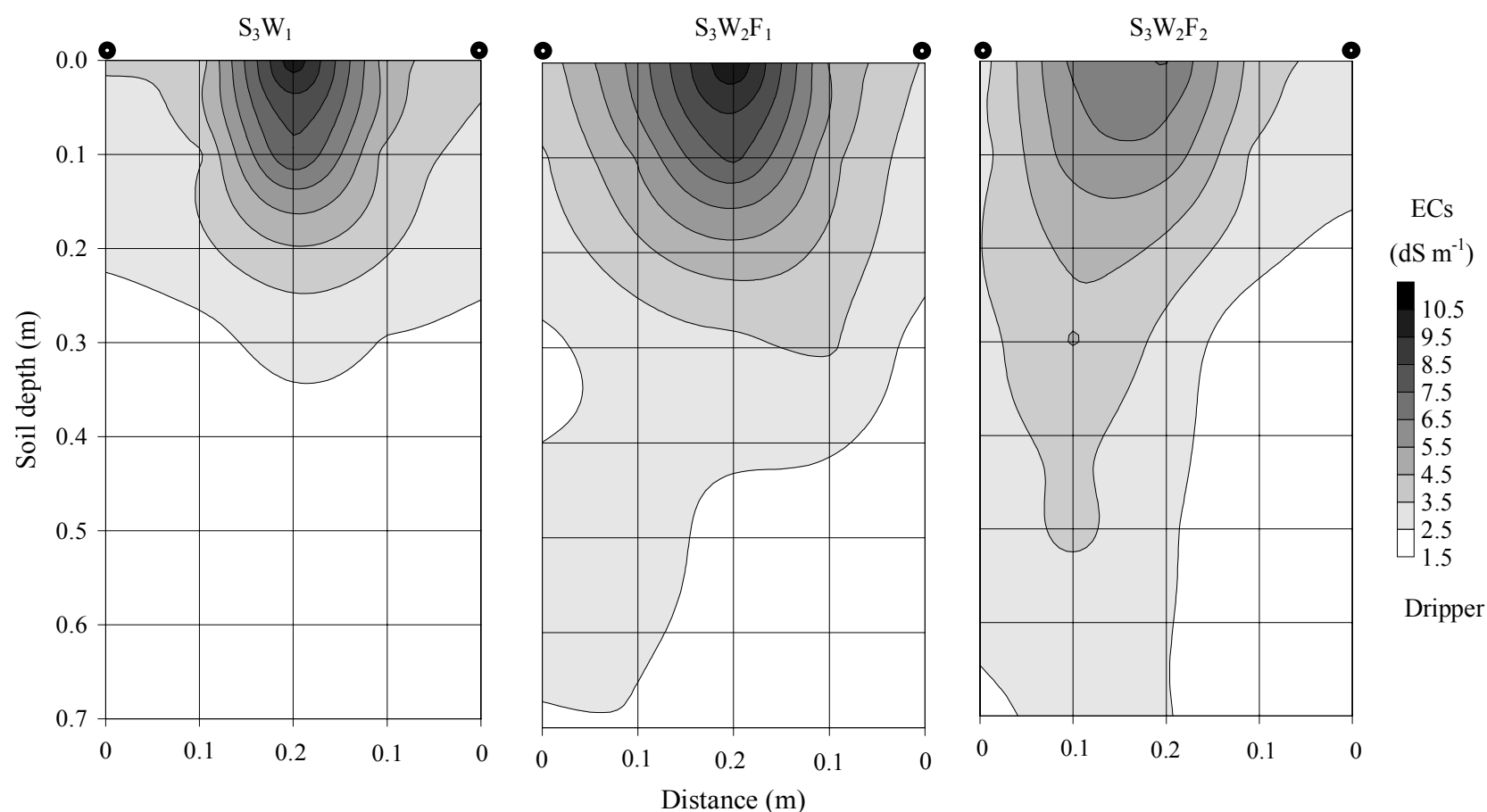

Figure 3. Salts distribution in the soil profile for the different irrigation water depths and management 
like the overlapping of the wetting zones of two adjacent emitters, soil hydraulic conductivity and discharge rate of the emitters also contribute to promote a specific salt concentration pattern (Shalhevet, 1973).

The plot which did not receive the leaching fraction $\left(\mathrm{S}_{3} \mathrm{~W}_{1}\right)$ developed the highest salt concentration between two adjacent wet bulbs and near the soil surface, while for $\mathrm{S}_{3} \mathrm{~W}_{2} \mathrm{~F}_{1}$ the region of highest salinity moved forward towards the laterals, probably due to the largest overlapping of the wet bulbs which dragged the salts laterally. Salt concentration in this region was lower on the $\mathrm{S}_{3} \mathrm{~W}_{2} \mathrm{~F}_{2}$ plot but the ECs increased for bottom soil depths as a result of the vertical movement or leaching of salts due to the great overlap of the bulbs on the day when $25.75 \mathrm{~mm}$ of water was applied. In addition, for different depths at a one point in space, salinity was higher in the upper soil layers than in the lower ones. Capillary rise as well as the lateral flow of water and salts after an irrigation event promotes salt accumulation in the shallower layers, because of the evaporation from the soil surface and water uptake by crop roots in this region. Jury et al. (1977) verified that higher water extractions by wheat in the shallower layers not only affected the movement of salt and water, but also the water content and concentrations.

Application of a theoretical leaching fraction of 0.2 in this study did not avoid the soil salinity build up, independent of the type of management adopted. On the other hand, irrigation water depth varied among the treatments and consequently the total amounts of salts added to soil was different according to water salinity and the depth of water applied. Figure 4 shows the increase in soil salinity for each millimeter of water applied for each of the treatments and soil depths. In general, largest increases in ECs occurred for the $\mathrm{W}_{1}$ treatments and $\mathrm{W}_{2} \mathrm{~F}_{1}$ resulted in the lowest values. Though the amount of salts added to soil in the treatments which received $\mathrm{W}_{2}$ was higher than that of $\mathrm{W}_{1}$, the results show that a larger water depth is required to reach the same increment of ECs, indicating that leaching occurred in $\mathrm{W}_{2}$ treatments being greater for $\mathrm{W}_{2} \mathrm{~F}_{1}$ than for $\mathrm{W}_{2} \mathrm{~F}_{2}$. Only for $\mathrm{S}_{3}$ at $0.1 \mathrm{~m}$ depth this tendency was not observed, probably due to the higher ECs in the first soil sampling at this depth that made the increment of soil salinity smaller for $\mathrm{S}_{3} \mathrm{~W}_{1}$, as it was calculated by the difference between the last and the first soil sampling.

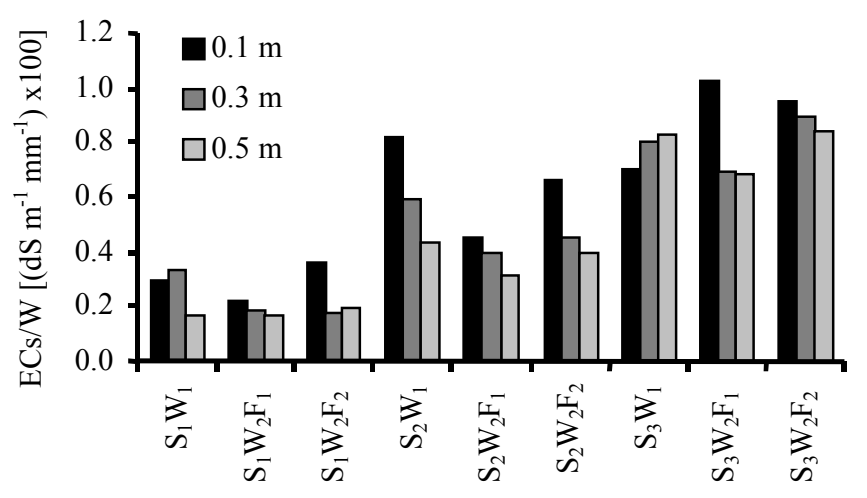

Treatment

Figure 4. Increment of soil salinity (ECs) for each millimeter of irrigation water applied (W) for each treatment and soil depth
The soil salinity may increase considerably after one season of irrigation with saline water (FAO, 1973). Under steady-state and ideal field conditions, soil water salinity generally ranges from a low level, not greatly exceeding that of the irrigation water near the soil surface, to levels many times that of the irrigation water salinity at the bottom of the root zone. However, steady-state conditions do not occur under most of the situations encountered in irrigated agriculture (Rhoades et al., 1992). In this study, the relatively small volume of irrigation water applied, which was equal to $2.0 \mathrm{~mm} \mathrm{~d}^{-1}$ on average (6.4 $\mathrm{mm}$ per irrigation), was not sufficient enough to raise the soil salinity so that the steady-state condition was reached. For a tomato crop, Shalhevet \& Yaron (1973) found that soil salinity was not well correlated to the leaching fraction and they attributed this fact to the short period of irrigation.

Leaching is less efficient for clay soils than for sandy soils because of the presence of preferential pathways and the larger electrolyte dispersion in the former. Therefore, relatively larger volumes of water pass through the soil layer without mixing with the soil water (Hoorn, 1981). The presence of a compacted layer at $0.2 \mathrm{~m}$ depth due to repeated ploughing along the years, which reduces the soil permeability and promotes a shallow root system seems to have contributed to decrease the leaching efficiency.

\section{CONCLUSIONS}

1. Soil salinity increased linearly with irrigation water salinity for all soil depths.

2. The leaching fraction of 0.2 was not efficient to avoid soil salinity build up, independent of the frequency of application.

3 . Salt accumulation occurred mainly near the soil surface and between the wet bulbs, at the wetting front.

4. There were indications that application of the leaching fraction would be more efficient when it is applied in all irrigations.

\section{ACKNOWLEDGMENTS}

To Fundação de Amparo à Pesquisa no Estado de São Paulo, FAPESP, for the financial support.

\section{LITERATURE CITED}

Ayers, R.S.; Westcot, D.W. Water quality for agriculture. Rome: FAO, 1985. 174p. FAO Irrigation and Drainage Paper 29 rev.1

Bresler, E. Two-dimensional transport of solutes during nonsteady infiltration from a trickle source. Soil Science Society of America, Proceedings, Madison, v.37, p.604-613, 1975.

Bresler, E.; McNeal, B.L.; Carter, D.L. Saline and sodic soils: Principles-dynamics-modeling. Berlin: Springer-Verlag, 1982. 236p. Advanced Series in Agricultural Sciences 10

Castilla, N.; Elias, F.; Fereres, E. Evapotranspiración de cultivos horticolas en invernadero en Almeria. Investigacion Agraria: Produccion y Proteccion Vegetal, Madrid, v.5, p.117-125, 1990.

FAO. Irrigation, drainage and salinity: An international sourcebook. Paris: UNESCO, 1973. 510p. 
Francois, L.E. Alfalfa management under saline conditions with zero leaching. Agronomy Journal, Madison, v.73, p.10421046, 1981.

Ghassemi, F.; Jakeman, A.J.; Nix, H.A. Salinisation of land and water resources. Sydney: University of New South Wales Press, 1995. 526p.

Hoffman, G.J. Guidelines for reclamation of salt-affected soils. In: Inter-American Conference on Salinity and Water Management Technology, 2, 1980, Juarez. Proceedings... Juarez, 1980. p.49-64.

Hoffman, G.J. Leaching fraction and root zone salinity control. In: Tanji, K.K. (ed.) Agricultural salinity assessment and management. New York: ASCE, 1990. cap.12, p.237-261.

Hoffman, G.J.; Durnford, D.S. Drainage design for salinity control. In: Skaggs, R.W.; Schilfgaarde, J. (ed.) Agricultural drainage. Madison: ASA/CSSA/SSSA, 1999. cap.17, p.579614. Agronomy, 38

Hoorn, J.W. Salt movement, leaching efficiency and leaching requirement. Agricultural Water Management, Amsterdam, v.4, n.4, p.409-428, 1981.

Jury, W.A.; Fluhlerk, H.; Stolzy, L.H. Influence of soil properties, leaching fraction and plant water uptake on solute concentration distribution. Water Resources Research, Washington, v.13, n.3, p.645-650, 1977.

Khan, A.A.; Yitayew, M.; Warrick, A.W. Field evaluation of water and solute distribution from a point source. Journal of Irrigation and Drainage Engineering, ASCE, New York, v.122, n.4, p.221-227, 1996.
Lunin, J.; Gallantin, M.H. Zonal salinization of the root system in relation to plant growth. Soil Science Society of America, Proceedings, Madison, v.29, p.608-612, 1965.

Martínez-Raya, A.; Castilla, N. Evapotranspiracion del pimiento en invernadero en Almeria. ITEA: Produccion Vegetal, Zaragoza, n.85, p.57-62, 1989.

Morrison, D.F. Multivariate statistical methods. 3.ed. New York: McGraw-Hill, 1990. 414p.

Petersen, F.H. Water testing and interpretation. In: Reed, D.W. (ed.) Water, media, and nutrition for greenhouse crops. Batavia: Ball, 1996. cap.2, p.31-49.

Rhoades, J.D.; Kandiah, A.; Mashali, A.M. The use of saline waters for crop production. Rome: FAO, 1992. 133p. FAO Irrigation and Drainage Paper 48

Richards, L.A. (ed.) Diagnosis and improvement of saline and alkali soils. Washington: United States Salinity Laboratory, 1954. 160p. USDA Agriculture Handbook 60

Shalhevet, J. Irrigation with saline water. In: Yaron, B.; Danfors, E.; Vaadia, Y. (ed.) Arid zone irrigation. Berlin: Springer-Verlag, 1973. cap.6, p.263-276. Ecological Studies 5

Shalhevet, J.; Bernstein, L. Effects of vertically heterogeneous soil salinity on plant growth and water uptake. Soil Science, Baltimore, v.106, p.85-93, 1968.

Shalhevet, J.; Yaron, B. Effect of soil and water salinity on tomato growth. Plant and Soil, Dordrecht, v.39, p.285-292, 1973.

Yaron, B.; Shalhevet, J.; Shimshi, D. Patterns of salt distribution under trickle irrigation. In: Hada, A.; Swartzendruber, D.; Rijtema, P.E.; Fuchs, M.; Yaron, B. (ed.) Physical aspects of soil water and salts in ecosystems. Berlin: Springer-Verlag, 1973. p.389-394. Ecological Studies 4 